\title{
Effects of the stage and number of lactation on milk yield of dairy cows kept in open barn during high temperatures in summer months
}

\author{
PAVEL NOVAK ${ }^{1}$, JITKA VOKRALOVA ${ }^{1}$ and JAN BROUCEK ${ }^{2}$
}

${ }^{1}$ University of Veterinary and Pharmaceutical Sciences, Brno, Czech Republic, ${ }^{2}$ Research Institute of Animal Production, Nitra, Slovakia

\section{Abstract}

Objective of this paper was evaluating the effect of high temperatures on production of milk of dairy cows in southern Moravia (Czech Republic, East Central Europe). We tested hypotheses that the milk efficiency of dairy cows kept in free-stall open barn without supplemental cooling is influenced of a month of summer period, lactation stage (LS) and lactation number (LN) of dairy cows. 193 Holstein cows were used. Three stages were stated according to the days in milk at the July 1: Stage 1-peak (0-50 d); Stage 2-mid lactation (51-120 d); Stage 3-late lactation (121-200 d). We found 63 summer (SumD) and 14 tropical days (TropD), 86 days with the temperature-humidity index (THI) above 72.0, and 26 days with the THI above 78.0, from May to September. The average monthly milk yields were statistically differed $(P<0.001)$ among $L S$, also among $L N$. We found significant interactions between LS and LN (May, $P<0.05$; June, $P<0.01$; July, $P<0.001$; August and September, $P<0.01)$. The average monthly milk yields of Stage 1 were gradually increased from May to July (from $33.94 \pm 8.99 \mathrm{~kg}$ on $36.62 \pm 6.62 \mathrm{~kg}$ ), then decreased to September $(30.05 \pm 5.69 \mathrm{~kg})$. Depression of milk was significant between July and August ( $36.62 \pm 6.62 \mathrm{~kg}$ vs. $32.26 \pm 5.88 \mathrm{~kg} ; P<0.01)$. Milk yield in the Stage 2 was the highest in May $(41.55 \pm 7.93 \mathrm{~kg})$ and then gradually decreased until October $(27.69 \pm 5.12$ $\mathrm{kg})$. Comparisons of months, LS and LN for whole observed period from May to October differed very highly significantly, there were recorded interactions month:LS $(P<0.001)$, month: $\operatorname{LN}(P<0.01)$, and LS:LN $(P<0.001)$. Dairy cows of Stage 1 were affected by the high temperatures in milk production for 305 days lactation significantly more than cows from Stage 2 (8954.4 $\pm 1526.9 \mathrm{~kg}$ vs. $9614.1 \pm 1488.6 \mathrm{~kg} ; P<0.05)$.

Keywords: dairy cows, milk yield, high temperatures, lactation stage, lactation number

\section{Zusammenfassung}

\section{Einfluss des Laktationsstadiums und der Laktationsnummer auf die Milchleistung der im Offenstall während höherer Temperaturen in den Sommermonaten gehaltenen Kühe}

Ausgewertet wurden der Einfluss der wärmeren Sommermonate auf die Leistungen von 193 Holstein Kühen die in Südböhmen in der Tschechischen Republik im Offenstall gehalten wurden. Berücksichtigt wurden die drei Laktationsstadien 1. (0.-50. Tag), 2. (51.-120. Tag) 
und 3. (nach dem 120. Laktationstag). Beobachtet wurden in den Monaten Mai bis September 63 Sommer-, 14 tropische Tage, 86 Tage mit einem Temperatur-Feuchte-Index (THI) über 72,0 und 26 Tage mit einem THI über 78,0. Signifikante Unterschiede ergaben sich sowohl bei den Laktationstadien als auch den Laktationsnummern sowie Interaktionen zwischen diesen. Die durchschnittliche tägliche Milchleistung im Stadium 1 stieg allmählich von Mai bis Juli von 33,94 $\pm 8,99 \mathrm{~kg}$ auf $36,62 \pm 6,62 \mathrm{~kg}$ und sank bis September auf $30,05 \pm 5,69 \mathrm{~kg}$. Diese Senkung der Leistung von Juli bis August von $36,62 \pm 6,62 \mathrm{~kg}$ bis $32,26 \pm 5,88 \mathrm{~kg}$ war signifikant. Im Stadium 2 erreichten die Tiere mit 41,55 \pm 7,93 kg die höchsten Leistungen und diese sanken dann allmählich bis Oktober auf 27,69 $\pm 5,12 \mathrm{~kg}$. Die Vergleiche der Monate, Laktationsstadien und -nummern erwiesen sich ebenso wie die Interaktionen zwischen diesen Beurteilungskriterien als hochsignifikant. Die Milchleistungen der Kühe im Stadium 1 wurden gegenüber dem Stadium 2 während der 305 Laktationstage durch höhere Temperaturen signifikant stärker beeinflusst (8 954,4 \pm 1526,9 kg bzw. $9614,1 \pm 1488,6$ kg).

Schlüsselwörter: Milchkühe, Milchleistung, hohe Temperaturen, Laktationsstadium, Laktationszahl

\section{Introduction}

Dairy cattle are adaptable to a wide range of climatic conditions, but can be severely challenged by heat stress. Repeated periods with high temperatures, with little air flow or cloud cover, are periods of concern. Although effects are more severe in hot climates, dairy cattle in areas with relatively moderate climates also are exposed to periods of heat stress. High temperatures depress milk production in many areas of the Europe. Heat stress occurs when any combination of environmental conditions cause the effective temperature of the environment to be higher than the animaks comfort zone (WOLLNY et al. 1998, TARALIK 1998, TAWFIK et al. 2000).

Summer depression of production causes significant economic loss in the dairy industry. The basic condition of management in dairy farms consists in understanding factors that affect milk production mostly, i.e. with the exception of nutrition and dairy cow health status also the lactation number (LN) and season of calving, technological systems, and especially microclimatic conditions (ZIEGLER and WENIGER 1990, GADER et al. 2007). These factors should be considered not only from the viewpoint of the total milk yield but also from that of the level of milk production, especially the slope of the lactation function. Important role plays the lactation stage (LS) (MAUST et al. 1972, JENTSCH et al. 2001), cows in mid lactation were most adversely affected and cows in early lactation least. The heat stress problem is getting worse as production levels continue to rise (FUQUAY 1981). Livestock performance is affected by heat stress because an animal having difficulty in losing heat will decrease its heat production by lowering feed intake (KLEIN and WENIGER 1986a, KAISER and WENIGER 1993). This act results in lower milk production. Generally, the higher producing the cow, the greater the heat load produced from digestion and metabolism (KAISER and WENIGER 1994a).

The upper critical air temperature for lactating cows is in the range of 24 to $27^{\circ} \mathrm{C}$ (FUQUAY 1981). However, critical temperatures will vary depending on several factors 
including degree of acclimatization, rate of production, pregnancy status, air movement around the animals and relative humidity (RH) (YOUSEF 1987). Cows under a permanent heat stress seem to strike a new metabolic balance with reduced energy intake and milk production and increased heat dissipation (NAUHEIMER-THONEICK et al. 1988). Life stage, conditioning, and nutritional and health status also influence the level of vulnerability to environmental stressors (HAHN 1999). Daily milk yield was depressed during short-term heat exposure. During the recovery phase, daily milk yield exhibited a further decline (BROUCEK et al. 1998, OMINSKI et al. 2002). However, according to BURMEISTER et al. (1990) lactating cows that had been exposed to periodic temperature stress showed a regenerative tendency in milk yield during recovery periods. AMANI et al. (2007) found that the lactation number (LN) had significant influences on all studied traits in high temperature conditions. There was a large significant difference between the first and second lactation and despite the fact that the maximum milk yield was reached in the fourth lactation it was not significantly different from the mean of the third lactation.

The temperature-humidity index (THI) is commonly used as a practical indicator for the degree of stress on dairy cattle caused by weather conditions (YOUSEF 1987, HUBBARD et al. 1999), because the THI incorporates the effects of both ambient temperature and $\mathrm{RH}$ in an index. In the warning to critical range of THI of 70-72, performance of dairy cattle is inhibited and cooling becomes desirable. At $\mathrm{THI}$ of $72-78$, milk production is seriously affected. In the dangerous category at $\mathrm{THI}$ of 78-82, the performance is severely affected and cooling of the animals become essential (DU PREEZ et al. 1990). All the adverse effects of the dangerous category are present in the emergency category at THI values of 82 and above, deaths may easily occur and cooling of the animals is absolutely essential (ARMSTRONG 1994, WEST 2003). Nienaber et al. (2003) cited emergenced THI value from 84. According to the review by JOHNSON (1987), milk yield starts to decline at 72 mean THI and losses in milk production are clearly related to changes in THI. Marked declines occur around 76-78 mean THI. A decrease in milk yield is $0.26 \mathrm{~kg} /$ day for each increase in THI. BERMAN (2005) reccommended the model heat balance which is accounted for effects of body weight, exposed body surface, milk production, hair coat, sweating, radiant heat, air velocity, humidity, and temperature.

The heat stress problem is acutely felt also in East Central European countries. The weather of these countries is characterized by moderate or high summer temperatures coupled with moderate humidity levels. Hot weather causes heat stress in dairy cows leading to declines in milk production each summer. These declines can be reduced or eliminated by using of open barns for optimum milk production.

Objective of this paper was evaluate the effect of high temperatures on production of milk of dairy cows in southern Moravia (Czech Republic, East Central Europe) in the year of 2004. We supposed that milk production of dairy cows kept in barn with good design is influenced of a month, LS and LN of dairy cows.

\section{Material and methods}

193 Holstein dairy cows were used. The month of calving was the main criterion to select dairy cows. We evaluated data from test milk records, taken at 30-d intervals of the period from December 2002 to May 2004 (all number of lactations). Three stages were stated 
according to the days in milk at the beginning of the hottest temperatures - 1st July: Stage 1 - peak (0-50 d - cows calved in May and June, the lactation started during the first milk performance control in May or June); Stage 2 - mid lactation (51-120 d - cows calved during March and April); Stage 3 - late lactation (121-200 d - cows calved in December to February). We compared total milk yields in 305-d lactation and total lactation, yield in 305-d lactation corrected in $4 \%$ content of fat (FCM) and index of persistency of dairy cows. Individual milk yields were recorded by Tru-tests.

Dairy cows were kept in reconstructed barn with three-row free-stall housing (rubber mattress flooring) and natural roof ventilation. Southern side of barn was opened. Cows had no supplemental cooling from fans or misters. During the observed period they were in the same housing conditions. Cows had access to unroofed, unbedded yards ( $\left.10 \mathrm{~m}^{2} / \mathrm{cow}\right)$.

Milking herringbone parlor was installed in a separate part of the stable. Cows were milked four times daily in the first 100 days of lactation. Milking was carried out twice daily from 101 day of lactation.

The total mixed ration was supplied to the troughs by a feeding wagon two a day during milking. Feeding was allowed throughout the $24 \mathrm{~h}$ period, except during milking. The energy content in feed ration for the cows in the peak phase of lactation was $7.05 \mathrm{MJ}$ $\mathrm{NEL} / \mathrm{kg}$ of dry matter (DM), in the second phase $6.43 \mathrm{MJ} \mathrm{NEL} / \mathrm{kg} \mathrm{DM}$, and in the third phase $5.48 \mathrm{MJ} \mathrm{NEL} / \mathrm{kg} \mathrm{DM}$, respectively. The composition of the total mixed ration was constant in the year and include corn silage, beet pulp, alfalfa haylage, hay, corn grain, wheat, concentrate mixture, water and mineral and energetic components. Feed ration included the factors for maintenance, growth, reproduction and lactation.

The meteorological data were recorded continuously by electronic probes inside of barn (put at animal height) and outside which connected to a data logger. We determinated the number of summer days (SumD) (maximum temperature above $25.0^{\circ} \mathrm{C}$ ) and tropical days (TropD) according to maximum temperature above $30.0^{\circ} \mathrm{C}$ from $24 \mathrm{~h}$ records in the inside of barn. THI was calculated as proposed by NIENABER et al. (1999) by combining maximum temperature $\left(\mathrm{T}_{\max },{ }^{\circ} \mathrm{C}\right)$ and average $\mathrm{RH}(\%)$ per day inside barn with the following expression:

$$
T H I=0.8 \cdot T_{\max }+\frac{\% \text { average } R H}{100} \cdot\left(T_{\max }-14.4\right)+46.4
$$

The data were analyzed with a statistical package STATISTIX 8 (2004). The normal distribution of data was evaluated by Wilk-Shapiro/Rankin Plot procedure. All data confirmed to a normal distribution. Among-group comparisons of the milk production and milk composition in each factor were analyzed using a General linear model ANOVA (General AOV/AOCV). The dependent variables were milk yield, FCM, length of lactation and index of persistency, and the independed variables were the factors month, stage and parity.

The homogeneity of variance of the observed variables in groups, whose average values are being compared, was calculated by preliminary variance tests, which determined whether the variability's are equal. Bartlett's test for equality of variance tests was applied with an unequal size of samples. The ratio of the largest within-group variance over the smallest was also tested (Pearson and Hartley test). Significant 
differences among means were tested by Bonferroni's test. We chose Bonferroni's method from Multiple Comparison Procedures since the number of dairy cows in groups was unequal. This test is generally more conservative than other from Statistix packet.

\section{Results and discussion}

The summer at 2003 year was in the East Central Europe extremely hot and high temperatures were manifested already from May. In the July, there were $17 \mathrm{SumD}$ and 7 TropD, in the August 23 SumD and 6 TropD (Table 1). The high temperatures were recorded also in September (11 SumD). In the present study were found 63 SumD and 14 TropD to the end of September in total.

Table 1

Meteorological parameters during observed period with high temperatures

Meteorologische Parameter während des Beobachtungszeitraumes

\begin{tabular}{|c|c|c|c|c|c|c|c|c|}
\hline \multirow{2}{*}{ Week } & \multicolumn{2}{|c|}{ T-inside } & \multirow{2}{*}{$\begin{array}{l}\text { T-outside } \\
\text { average }\end{array}$} & \multirow{2}{*}{$\begin{array}{c}\text { THI } \\
\text { average }\end{array}$} & \multicolumn{2}{|c|}{ Days with } & \multirow{2}{*}{ SumD/TropD } & \multirow{2}{*}{ Month } \\
\hline & average & $\max$ & & & $\mathrm{THI}>72$ & $\mathrm{THI}>78$ & & \\
\hline 1 & 16.9 & 20.4 & 16.1 & 66.7 & 2 & 0 & 0 & May \\
\hline 2 & 14.6 & 19.2 & 12.6 & 65.0 & 1 & 0 & 0 & \\
\hline 3 & 16.6 & 21.3 & 14.4 & 67.9 & 2 & 0 & $1 / 0$ & \\
\hline 4 & 14.5 & 19.3 & 11.9 & 64.8 & 0 & 0 & 0 & \\
\hline 5 & 18.6 & 23.4 & 16.6 & 70.9 & 4 & 0 & $2 / 0$ & June \\
\hline 6 & 20.8 & 25.7 & 18.9 & 75.0 & 5 & 2 & $5 / 1$ & \\
\hline 7 & 19.7 & 24.3 & 17.8 & 72.2 & 4 & 0 & $3 / 0$ & \\
\hline 8 & 19.2 & 23.2 & 17.3 & 71.3 & 4 & 0 & $1 / 0$ & \\
\hline 9 & 19.1 & 23.9 & 17.3 & 72.2 & 5 & 0 & $1 / 0$ & July \\
\hline 10 & 20.5 & 25.0 & 19.3 & 73.7 & 6 & 0 & $4 / 0$ & \\
\hline 11 & 18.3 & 22.3 & 15.9 & 69.9 & 3 & 0 & $1 / 0$ & \\
\hline 12 & 25.6 & 31.2 & 24.8 & 82.9 & 7 & 7 & $7 / 6$ & \\
\hline 13 & 21.8 & 26.1 & 19.8 & 75.0 & 5 & 2 & $4 / 1$ & \\
\hline 14 & 23.1 & 29.6 & 21.5 & 79.7 & 7 & 6 & $7 / 2$ & August \\
\hline 15 & 23.8 & 29.1 & 22.6 & 78.6 & 7 & 4 & $7 / 2$ & \\
\hline 16 & 22.9 & 28.7 & 22.2 & 78.2 & 7 & 4 & $6 / 2$ & \\
\hline 17 & 20.0 & 24.5 & 18.1 & 72.6 & 6 & 0 & $3 / 0$ & \\
\hline 18 & 19.7 & 24.6 & 18.8 & 72.4 & 5 & 0 & $5 / 0$ & September \\
\hline 19 & 19.8 & 25.4 & 18.0 & 73.1 & 5 & 1 & $4 / 0$ & \\
\hline 20 & 17.8 & 22.4 & 16.4 & 69.4 & 1 & 0 & $2 / 0$ & \\
\hline 21 & 14.6 & 18.6 & 13.0 & 63.9 & 0 & 0 & 0 & \\
\hline 22 & 14.8 & 19.2 & 12.3 & 65.3 & 0 & 0 & 0 & \\
\hline 23 & 16.2 & 20.9 & 14.5 & 67.6 & 0 & 0 & 0 & October \\
\hline 24 & 10.0 & 13.3 & 7.6 & 56.4 & 0 & 0 & 0 & \\
\hline 25 & 11.3 & 14.5 & 9.1 & 58.1 & 0 & 0 & 0 & \\
\hline 26 & 15.3 & 17.7 & 13.1 & 63.2 & 0 & 0 & 0 & \\
\hline $\begin{array}{l}\text { Average/ } \\
\text { total }\end{array}$ & 18.3 & 22.8 & 16.5 & 70.2 & 86 & 26 & $63 / 14$ & \\
\hline
\end{tabular}

$\mathrm{T}$ temperature in ${ }^{\circ} \mathrm{C}$, $\mathrm{THI}$ temperature-humidity index, SumD number of summer days (maximum $\mathrm{T}$ above $25^{\circ} \mathrm{C}$ ), TropD number of tropical days (maximum T above $30.0^{\circ} \mathrm{C}$ )

The values of THI for months May to October are mentioned also in the Table 1. Eighty-six days with the value above 72.0, which is critical stress category, were found. At 26 days were recorded values higher then 78.0, which is dangerous stress category. 
The average monthly milk yields were statistically differed $(P<0.001)$ among lactation stages from May to October, also among lactation orders in May, June and July, August (Table 2). We found significant interactions between LS and LN (May, $P<0.05$; June, $P<0.01$; July, $P<0.001$; August and September, $P<0.01$ ).

Table 2

The evaluating of average milk yield (kg milk) during hot period Durchschnittliche tägliche Milchleistung $(\mathrm{kg})$ während der wärmeren Periode

\begin{tabular}{|c|c|c|c|c|c|c|c|}
\hline \multirow{2}{*}{ Stage } & \multirow{2}{*}{ N } & \multirow{2}{*}{ Mean } & \multirow{2}{*}{ SD } & \multirow{2}{*}{ SE } & \multicolumn{3}{|c|}{ Significance ( $P$-values) } \\
\hline & & & & & LS & LN & Interaction \\
\hline \multicolumn{8}{|l|}{ May } \\
\hline 1 & 66 & 33.94 & 8.99 & 1.11 & $* * *$ & $* * *$ & * \\
\hline 2 & 61 & 41.55 & 7.93 & 1.01 & & & \\
\hline 3 & 66 & 32.02 & 6.84 & 0.84 & $S 2: S 1^{* * *}$ & LN1:LN2*** & \\
\hline Total & 193 & 35.69 & 8.91 & 0.64 & $\begin{array}{l}\mathrm{S} 2: \mathrm{S} 3^{* * *} \\
\mathrm{~S} 1: 3^{* * *}\end{array}$ & $\begin{array}{l}\text { LN1:LN3*** } \\
\text { LN1:LN4* }\end{array}$ & \\
\hline \multicolumn{8}{|l|}{ June } \\
\hline 1 & 66 & 35.95 & 6.40 & 0.79 & $* * *$ & $* * *$ & $* *$ \\
\hline 2 & 61 & 38.20 & 6.55 & 0.84 & & & \\
\hline 3 & 66 & 29.58 & 6.07 & 0.75 & $\mathrm{~S} 2, \mathrm{~S} 1: \mathrm{S} 3^{* * *}$ & LN3,LN2:LN1*** & \\
\hline Total & 193 & 34.48 & 7.29 & 0.52 & & & \\
\hline \multicolumn{8}{|l|}{ July } \\
\hline 1 & 66 & 36.62 & 6.62 & 0.81 & $* * *$ & $* *$ & $* * *$ \\
\hline 2 & 61 & 34.56 & 5.97 & 0.76 & & & \\
\hline 3 & 66 & 27.09 & 5.67 & 0.69 & $\mathrm{~S} 1, \mathrm{~S} 2: \mathrm{S} 3^{* * *}$ & LN3,LN2:LN1** & \\
\hline Total & 193 & 32.71 & 7.35 & 0.53 & & & \\
\hline \multicolumn{8}{|c|}{ August } \\
\hline 1 & 66 & 32.26 & 5.88 & 0.72 & $* * *$ & ns & $* *$ \\
\hline 2 & 61 & 33.25 & 6.33 & 0.81 & & & \\
\hline 3 & 66 & 25.41 & 6.29 & 0.77 & $\mathrm{~S} 2, \mathrm{~S} 1: \mathrm{S} 3^{* * *}$ & & \\
\hline Total & 193 & 30.23 & 7.07 & 0.51 & & & \\
\hline \multicolumn{8}{|c|}{ September } \\
\hline 1 & 66 & 30.05 & 5.69 & 0.70 & $* * *$ & ns & $* *$ \\
\hline 2 & 61 & 28.77 & 5.25 & 0.67 & & & \\
\hline 3 & 66 & 23.22 & 7.01 & 0.86 & $\mathrm{~S} 1, \mathrm{~S} 2: \mathrm{S} 3^{* * *}$ & & \\
\hline Total & 193 & 27.31 & 6.72 & 0.48 & & & \\
\hline \multicolumn{8}{|c|}{ October } \\
\hline 1 & 66 & 30.24 & 6.05 & 0.74 & $* * *$ & ns & ns \\
\hline 2 & 61 & 27.69 & 5.12 & 0.65 & & & \\
\hline 3 & 66 & 16.50 & 8.94 & 1.10 & $\mathrm{~S} 1, \mathrm{~S} 2: \mathrm{S} 3^{* * *}$ & & \\
\hline Total & 193 & 24.74 & 9.17 & 0.66 & & & \\
\hline
\end{tabular}

$\mathrm{N}$ number of animals, SD standard deviation, SE standard error of the mean, LS stage of lactation, LN parity ${ }^{*} P<0.05, \quad{ }^{*} P<0.01, \quad{ }^{*} * *<0.001$, ns not significant, S1 to 50th day of lactation, S2 from 51 to 120 days of lactation, S3 from 121 to 200 days of lactation

The average monthly milk yields of Stage 1 (peak) were gradually increased from May to July (from $33.94 \pm 8.99 \mathrm{~kg}$ on $36.62 \pm 6.62 \mathrm{~kg}$ ). Then monthly milk yields started decreasing through August ( $32.26 \pm 5.88 \mathrm{~kg})$ to September $(30.05 \pm 5.69 \mathrm{~kg})$. Differences between months of ascending period (May, June and July) and descending period (August, September and October) were significant (Table 3). 
Table 3

Differences among months according to lactation stage and lactation number

Differenz zwischen den Monaten in Bezug auf Laktationsstufe und -nummer

\begin{tabular}{|c|c|c|c|c|c|}
\hline Index & $\mathrm{N}$ & Mean & SD & SE & Significance ( $P$-values) \\
\hline \multicolumn{6}{|l|}{ LS } \\
\hline 1 & 396 & 33.18 & 7.13 & 0.36 & $M: S, O^{*} ;$ Ju:S,O***; Ju:A*; Jl:S,O***; Jl:A** \\
\hline 2 & 366 & 34.00 & 7.91 & 0.41 & $M: J, A, S, O^{* * *} ; J u: A, S, O^{* * *} ; J: S, O^{* * *} ; A: S^{* *} ; A: O^{* * *}$ \\
\hline 3 & 396 & 25.64 & 8.45 & 0.42 & $M: J I, A, S, O^{* * *} ; J u: S, O^{* * *} ; J u: A^{* *} ; J: O^{* * *} ; A: O^{* * *} ; S: O^{* * *}$ \\
\hline \multicolumn{6}{|l|}{$\mathrm{LN}$} \\
\hline 1 & 426 & 29.74 & 6.00 & 0.29 & $M: S, O^{* * *} ; M: A^{*} ; J u: S, O^{* * *} ; J l S, O^{* * *} ; A: O^{* *}$ \\
\hline 2 & 300 & 32.44 & 9.17 & 0.53 & $M: S, O^{* * *} ; M: A^{* *} ; J u: S, O^{* * *} ; J: S, O^{* * *} ; A: O^{* *}$ \\
\hline 3 & 234 & 30.52 & 10.31 & 0.67 & $M: S, O^{* * *} ; M: A^{*} ; J u: S, O^{* * *} ; J: S, O^{* * *} ; A: O^{* * *}$ \\
\hline 4 & 102 & 31.69 & 9.96 & 0.98 & $M: S, O^{* * *} ; M: A^{*} ; J u: S^{*} ; J u: O^{* * *}$ \\
\hline 5 & 96 & 30.81 & 10.78 & 1.10 & $\mathrm{M}: \mathrm{O}^{* *} ; \mathrm{Ju}: \mathrm{O}^{*} ; \mathrm{Jl}: \mathrm{O}^{*}$ \\
\hline
\end{tabular}

$\mathrm{N}$ number of animals, SD standard deviation, SE standard error of the mean, LS stage of lactation, LN parity ${ }^{*} P<0.05, \quad{ }^{*} P<0.01, \quad{ }^{* *} P<0.001, \quad$ S1 to 50th day of lactation, S2 from 51 to 120 days of lactation, S3 from 121 to 200 days of lactation, M May, Ju June, Jl July, A August, S September, O October

The difference between July and August, the two hottest months, is important for an assessment of the effects of high temperatures on milk yield. Depression of milk was expressive and significant in this Stage 1 (July $36.62 \pm 6.62 \mathrm{~kg}$ vs. August $32.26 \pm 5.88 \mathrm{~kg} ; P<0.01$ ).

Milk yield in Stage 2 was the highest in May, that is, as an immediate response to exposure to high temperatures $(41.55 \pm 7.93 \mathrm{~kg})$, and then it was steadily decreasing until October $(27.69 \pm 5.12 \mathrm{~kg})$. Differences between May and August and September and October were very significant (Table 3 ). However, in the present study were only a small difference between the months of July and August ( $34.56 \pm 5.97 \mathrm{~kg}$ vs. $33.25 \pm 6.33 \mathrm{~kg}$ ). Milk yield in Stage 3 decreased regularly. Even though the individual months differed statistically (Table 3), presume that this was caused by the high temperatures but by progressing lactation.

The most affected by the high temperatures were cows placed in $\mathrm{LN}$ of 4 . The greatest drop of absolute difference in the losses in the period from May to October was recorded in older cows from the $3 \mathrm{rd}$ to 5 th lactations $(15.47 \mathrm{~kg} ; 15.99 \mathrm{~kg}$ and $14.7 \mathrm{~kg})$. The greatest differences between May and August were observed in LN 4 and 5 (4.16 kg and $4.5 \mathrm{~kg}$ ).

Table 4 shows the evaluation of the entire observed period from May to October. The differences between individual months, $L S$ and $L N$ were significantly very different, and month:LS $(P<0.001)$, month:LN $(P<0.01)$, and LS:LN $(P<0.001)$ interactions were recorded.

Table 5 shows that milk production of dairy cows that were in the peak stage (Stage 1) in July and August (0- 50 days in milk), were affected by the high temperatures for 305 days of lactation significantly more than cows in the mid lactation (Stage 2) (51-120 days in milk) stage ( $8954.4 \pm 1526.9 \mathrm{~kg}$ vs. $9614.1 \pm 1488.6 \mathrm{~kg} ; P<0.05)$. Very highly significant difference was found among $\mathrm{LN}$ in the index of persistency $(P<0.001)$.

It is well known that cows reduce production during summer months with either acute or chronic exposure to heat stress. An ambient indicator of heat stress (i.e., temperaturehumidity index) is traditionally used for prediction of milk yield during summer. JOHNSON (1987) showed that milk production will be reduced whenever THI exceeds a value of 72 . Though many studies have examined the effect of heat stress on same day milk production, 
other studies suggest that the more significant impact might occur a few days after dairy cows are exposed to extreme heat stress (WEST et al. 2003, BROUCEK et al. 1998).

Table 4

Evaluation of whole observed period (kg milk)

Durchschnittliche tägliche Milchleistung während der gesamten Beobachtungsperiode

\begin{tabular}{|c|c|c|c|c|c|c|c|c|}
\hline \multirow{2}{*}{ LN } & \multirow{2}{*}{$\mathrm{N}$} & \multirow{2}{*}{ Mean } & \multirow{2}{*}{ SD } & \multirow{2}{*}{ SE } & \multicolumn{4}{|c|}{ Significance ( $P$-values) } \\
\hline & & & & & Month & LS & LN & Interaction \\
\hline \multicolumn{9}{|l|}{ Month } \\
\hline May & 193 & 35.69 & 8.91 & 0.64 & $* * *$ & $* * *$ & $* * *$ & Mo:LS \\
\hline June & 193 & 34.48 & 7.29 & 0.52 & & & & $* * *$ \\
\hline July & 193 & 32.71 & 7.35 & 0.53 & & & & \\
\hline August & 193 & 30.23 & 7.07 & 0.51 & & & & \\
\hline September & 193 & 27.31 & 6.73 & 0.48 & Mo:JI,A,S,O** & & & \\
\hline October & 193 & 24.74 & 9.17 & 0.66 & & & & \\
\hline Total & 1158 & 30.86 & 8.71 & 0.25 & & & & \\
\hline \multicolumn{9}{|l|}{ LS } \\
\hline 1 & 396 & 33.18 & 7.13 & 0.36 & & $\mathrm{~S} 2, \mathrm{~S} 1: \mathrm{S} 3^{* * *}$ & & Mo:LN \\
\hline 2 & 366 & 34.00 & 7.91 & 0.41 & & & & $* * *$ \\
\hline 3 & 396 & 25.64 & 8.45 & 0.42 & & & & \\
\hline Total & 1158 & 30.86 & 8.71 & 0.25 & & & & \\
\hline \multicolumn{9}{|l|}{ LN } \\
\hline 1 & 426 & 29.74 & 6.00 & 0.29 & & & LN2,LN3:LN1 ${ }^{* * *}$ & LS:LN \\
\hline 2 & 300 & 32.44 & 9.17 & 0.53 & & & & $14.73^{* * *}$ \\
\hline 3 & 234 & 30.52 & 10.31 & 0.67 & & & & 0.0000 \\
\hline 4 & 102 & 31.69 & 9.96 & 0.98 & & & & \\
\hline 5 & 96 & 30.81 & 10.78 & 1.10 & & & & \\
\hline Total & 1158 & 30.86 & 8.71 & 0.25 & & & & \\
\hline
\end{tabular}

$\mathrm{N}$ number of animals, SD standard deviation, SE standard error of the mean, LS stage of lactation, LN parity ${ }^{*} P<0.05, \quad{ }^{* *} P<0.01, \quad{ }^{* *} P<0.001, \quad S 1$ to 50 th day of lactation, S2 from 51 to 120 days of lactation, S3 from 121 to 200 days of lactation, M May, Ju June, JI July, A August, S September, O October

At the present work were evaluated thermal periods from May to October, however, markedly aggravated condition were during July and August. Temperature during the hottest hours of the day could probably exceed the heat dissipating capacity of evaporative heat loss by both panting and sweating in observed cows. In this condition, the metabolic activity was affected to a slight extent by heat stress, and milk yield could decrease.

Generally, high ambient temperatures depressively affect milk production (Johnson 1986; BALTAY, 2002; Soch, 2005). However, the effects of hot environment on milk production vary with the LS. Early lactating cows can be more sensitive to the effect of heat than late lactating cows. The process associated with maintenance, digestion and metabolism. Individual variation in lactating yield and shape of the lactation curve under periodic heat stress indicates the possibility of discussing productive adaptation in high performance cattle more deeply from a genetic perspective (BURMEISTER et al. 1990).

There are adversed opinions on this LS effect. Milk production could be more influenced in early-lactation cows for their negative energy balance, or strongly supported by tissue stores mobilisation (GADER et al. 2007). Cows in the early stage of lactation extensively utilize body reserves and are less dependent on consumed feed energy. They are on the higher level of production, despite of consuming the least feed (SOCH et al. 2000). 
Table 5

The evaluating of lactation ( $\mathrm{kg}$ milk)

Auswertung der Laktationsleistung (kg Milch)

\begin{tabular}{|c|c|c|c|c|c|c|c|}
\hline \multirow{2}{*}{ Stage } & \multirow{2}{*}{$\mathrm{N}$} & \multirow{2}{*}{ Mean } & \multirow{2}{*}{ SD } & \multirow{2}{*}{ SE } & \multicolumn{3}{|c|}{ Significance ( $P$-values) } \\
\hline & & & & & LS & LN & Interaction \\
\hline \multicolumn{8}{|c|}{ Milk for 305 days } \\
\hline 1 & 66 & 8985.4 & 1526.9 & 187.94 & * & ns & ns \\
\hline 2 & 61 & 9614.1 & 1488.6 & 190.60 & & & \\
\hline 3 & 66 & 9254.3 & 1570.6 & 193.32 & $\mathrm{~S} 2: \mathrm{S} 1, \mathrm{~S} 3^{*}$ & & \\
\hline Total & 193 & 9276.1 & 1543.5 & 111.10 & & & \\
\hline \multicolumn{8}{|c|}{ FCM for 305 days } \\
\hline 1 & 66 & 8260.4 & 1305.7 & 160.72 & ns & ns & ns \\
\hline 2 & 61 & 8696.8 & 1350.4 & 172.89 & & & \\
\hline 3 & 66 & 8491.6 & 1460.4 & 179.77 & & & \\
\hline Total & 193 & 8477.0 & 1378.0 & 99.23 & & & \\
\hline \multicolumn{8}{|c|}{ Milk for whole lactation } \\
\hline 1 & 66 & 10088 & 2265.4 & 278.85 & ns & ns & ns \\
\hline 2 & 61 & 10491 & 1994.4 & 255.36 & & & \\
\hline 3 & 66 & 10186 & 2374.0 & 292.22 & & & \\
\hline Total & 193 & 10249 & 2217.5 & 159.62 & & & \\
\hline \multicolumn{8}{|c|}{ Length of whole lactation } \\
\hline 1 & 66 & 359.56 & 67.28 & 8.28 & ns & ns & ns \\
\hline 2 & 61 & 350.84 & 52.71 & 6.75 & & & \\
\hline 3 & 66 & 351.85 & 63.61 & 7.83 & & & \\
\hline Total & 193 & 354.17 & 61.53 & 4.42 & & & \\
\hline \multicolumn{8}{|c|}{ Index of persistency (P21) } \\
\hline 1 & 66 & 87.30 & 11.15 & 1.37 & ns & $* * *$ & ns \\
\hline 2 & 61 & 85.08 & 10.97 & 1.40 & & & \\
\hline 3 & 66 & 87.17 & 13.52 & 1.66 & & LN1:LN3,LN2,LN5,LN4*** & \\
\hline Total & 193 & 86.55 & 11.94 & 0.86 & & & \\
\hline
\end{tabular}

$\mathrm{N}$ number of animals, SD standard deviation, SE standard error of the mean, LS stage of lactation, LN parity ${ }^{*} P<0.05, \quad{ }^{* *} P<0.01, \quad{ }^{* * *} P<0.001$, ns not significant

JOHNSON (1987) wrote that the average daily losses in milk production for early stage cows were $5.5 \mathrm{~kg} / \mathrm{day} / \mathrm{cow}$, mid stage $2.6 \mathrm{~kg} / \mathrm{day} / \mathrm{cow}$, and late stage $2.9 \mathrm{~kg} / \mathrm{day} / \mathrm{cow}$ for the first 55-day period during the summer. Heat stress in the fresh cow may impair health, decrease milk yield, and lengthen time to peak milk production and peak feed intake. However, the early cows tended to recover more during the last 55 days of the summer.

At the present work, the average monthly milk yields of peak stage (Stage 1) were gradually increased from May to July and then decreased to September. Distinc limit for production of milk was midst July and August and milk loss between those months was expressive. Milk yield in the mid lactation stage (Stage 2) was the highest in May and then was production gradually decreasing until October. This might indicate that cows from Stage 1 were afflicted by the hyperthermal stress the most. However, this reduction of the amount of milk yield in the present study distribution of the year can change in relation to many other factors, in particular to the milk yield level and to the reproduction phase. 
Only after in the present work evaluated the 305-day period of lactation did receive the final answer. Dairy cows of Stage 1 were affected by the high temperatures in milk production for 305 days lactation significantly more than cows from mid lactation (Stage 2) $(8954.4 \pm 1526.9 \mathrm{~kg}$ vs. $9614.1 \pm 1488.6 \mathrm{~kg} ; P<0.05)$. The highest milk yield in lactation was found in cows, which were at the beginning of July on their 51 to 120 days in milk. That means that the high temperatures markedly limited efficiency of cows from Stage 1.

The higher producing cows of Stage 2 were probably less sensitive to the effects of high ambient temperatures. This contradicts the findings of MAUST et al. (1972) that midlactation cows were most adversely influenced by heat stress, whereas those in late lactation were affected fairly and those in early lactation the least. These authors also remind that cows in mid-lactation were most affected, but they seem to recover from one or more days of thermal stress better than cows in late lactation (MAUST et al. 1972). The generally valid statements on adaptability are difficult to make because of considerable individual differences in reaction patterns between animals. However, the broad spectrum of variation in reaction to heat stress under which a sufficient number of cows showed high lactation performance, allowed the selection of suitable breeding animals for regions with high environmental temperatures (KLEIN and WENIGER 1986b). Also, the preliminary heat treatment influences the reactions of the cows only during the initial stage of the alternating heat stress. The change to the constant heat stress results in a temporary relief (GROSSMANN et al. 1984, KAISER and WENIGER 1994b).

In the present study were found similarly the lowest milk production in whole lactation in cows of Stage 1 spending summer months in their peak production (about 50 days), however the differences were no significant (10088 kg; 10491 kg; $10186 \mathrm{~kg}$ ).

The effects of heat stress may be more pronounced in older cows than first-lactation heifers. At the present work the most affected by the high temperatures were cows of higher parities. THOMPSON et al. (1999) reported a significant reduction in 305-day milk production of second-lactation or older cows that was not seen in first-lactation heifers. It is a common field observation that heifers don't suffer heat stress to the extents that mature cows do. Older cows were affected more severely because they had higher feed consumption, therefore digest more, produced more milk, and had more fatty insulation preventing heat loss, as compared to primiparous cows. ZÄHNER et al. (2004) indicated that the prevalent climatic conditions on the farms during the day induced stronger thermoregulatory responses in the cows than the conditions that prevailed during the night. However, within the measured range of climatic conditions, the cows were hardly exposed to severe cold or heat stress and thus able to cope with these conditions.

In conclusion, milk production of cows is influenced by environmental factors, especially of high temperatures during summer. Heat stress is caused primarily by high air temperature, but can be intensified by high humidity, thermal radiation and low air movement. Improving performance of animals under warm conditions involves breeding and management and modifying the environment. Hot weather conditions reduce dry matter intake and level of decreasing of milk production is also affected by stage of lactation. 
Dairy cows of early stage were affected by the high temperatures in milk production for 305 days lactation significantly more than cows from mid lactating stage. We can concluded that heat stress can cause significant production and economic losses on commercial dairy farms. Therefore, appropriate housing facilities and equipment to protect dairy cows from climatic extremes have significant importance for maintaining of production.

For protecting dairy cows in East Central European countries against heat stress, several practical minimum precautions have been proposed. However, further research on heat stress on dairy cattle is essential if the dairy industry is determined to achieve more cost-effective milk production, improved herd and udder health. It will probably be necessary to study more closely the methods of the air-cooling also in open barns.

\section{Acknowledgements}

This study was conducted with the support of Grant Project No QF. 4036 awarded by the NAZV MZe Czech Republic.

\section{References}

Atyl H (2000) Genetic relationship between days open and days dry with milk yield in a Herd of Holstein Friesian cattle. Arch Tierz 43, 583-90

Armstrong DV (1994) Heat stress interaction with shade and cooling. J Dairy Sci 77, 2044-50

Baltay Z (2002) Influence of time of day the milk and saison on the somatic cell count under Hungarian conditions. Arch Tierz 45, 349-57

Berman A (2005) Estimates of heat stress relief needs for Holstein dairy cows. J Anim Sci 83, 1377-84

Broucek J, Uhrincat M, Kovalcikova M, Arave CW (1998) Effects of heat environment on performance behaviour and physiological responses of dairy cows. In: Chastain JP (ed) Fourth International Dairy Housing Conference, Jan 28-30, St. Louis, ASAE Publication 01-98, Conference proceedings, 217-22

Burmeister GA, Ziegler H, Weniger JH (1990) Performance, thermoregultaion and energy metabolism of Holstein-Friesian cows under heat stress. 2nd communication: Reactions of performance and parameters of adaption. Züchtungsk 62, 265-76 [in German]

Du Preez JH, Hatting PJ, Giesecke WH, Eisenberg BE (1990) Heat stress in dairy cattle and other livestock under southern african conditions. Monthly temperature-humidity index mean values and their significance in the performance of dairy cattle. Onderstepoort. J Vet Res 57, 241-8

Fuquay JW (1981) Heat stress as it affects animal production. J Anim Sci 52, 164-74

Gader AZA, Ahmed M-KA, Musa LM-A, Peters KJ (2007) Milk yield and reproductive performance of Friesian cows under Sudan tropical conditions. Arch Tierz 50, 155-64

Grossmann R, Steinhauff D, Weniger JH (1984) Reactions to heat stress of cows acclimatized to different degrees. 1st communication: Performance and thermoregulation. Zschr Tierz Züchtungsbiol 101, 182-7 [in German]

Hahn GL (1999) Dynamic responses of cattle to thermal heat loads. J Anim Sci 77, Suppl 2/J Dairy Sci 82 , Suppl 2, 10-20

Hubbard KG, Stooksbury DE, Hahn GL, Mader TL (1999) A climatologic perspective on feedlot cattle performance and mortality related to the temperature-humidity index. J Prod Agric 12, 650-3

Jentsch W, Derno M, Weiher O (2001) Heat production of dairy cows in dependence on milk yield - a study. Arch Tierz 44, 599-610

Johnson HD (1986) The effects of temperature and thermal balance on milk production. In: Johnson Harold D (ed) Limiting the Effects of Stress on Cattle. Western Regional Research Project, W-135 Publication, Research Bulletin 512, 33-45

Johnson HD (1987) Bioclimate effects on growth, reproduction and milk production. In: Johnson Harold D. (ed) Bioclimatology and the Adaptation of Livestock, World Animal Science, B5, Chapter 3, Elsevier Science Publishers B.V., Amsterdam, The Nederlands, 35-57 
Kaiser D, Weniger JH (1993) In vivo and in vitro investigations for nutrient digestibility and heat production of ruminants under heat stress and different nutritional levels. I. In vivo investigations Research background, experimental design, feed and energy intakes. Arch Tierz 36, 607-19 [in German]

Kaiser D, Weniger JH (1994) In vivo and in vitro investigations for nutrient digestibility and heat production of ruminants under heat stress and different nutritional levels. II. In vivo investigations nutrient digestibility and heat production. Arch Tierz 37, 19-30 [in German]

Kaiser D, Weniger JH (1994) In vivo and in vitro investigations for nutrient digestibility and heat production of ruminants under heat stress and different nutritional levels. III. In vivo investigations nitrogen-balance, energy-balance and physiological parameters of thermoregulation. Arch Tierz 37, 327-37 [in German]

Klein HGF, Weniger JH (1986a) Effect of temperature stress during lactation on performance and thermoregulation of German Friesians. I. Systematic effects, influence of thermal load on yield during part and whole lactations, correlation between traits. Zschr Tierz Züchtungsbiol 103, 279-96 [in German]

Klein HGF, Weniger JH (1986b) Effect of temperature stress during lactation on performance and thermoregulation of German Friesians. II. Influence of temperature stress on thermoregulation, depending on the milk yield. Zschr Tierz Züchtungsbiol 103, 297-306 [in German]

Maust LE, McDowell RE, Hooven NW (1972) Effects of summer weather on performance of Holstein cows in three stages of lactation. J Dairy Sci 55, 1133-9

Nauheimer-Thoneick H, Thomas CK, Weniger JH (1988) Investigations on energy metabolism of lactating cows under heat stress III. Effects of longterm high environmental temperature on parameters of thermoregulation, food intake and milk yield. Züchtungsk 60, 376-87 [in German]

Nienaber JA, Hahn GL, Eigenberg RA (1999) Quantifing livestock responses for heat stress management: a review. Int J Biometeorol 42, 183-8

Nienaber JA, Hahn GL, Brown-Brandl TM, Eigenberg RA (2003) Heat stress climatic conditions and the physiological responses of cattle. In: Janni Kevin A (ed) Fifth International Dairy Housing Conference (29-31 January 2003, Fort Worth, Texas, USA), ASAE Publication Number 701P0203, 255-262

Ominski KH, Kennedy AD, Wlittenberg KM, Moshtaghi Nia SA (2002) Physiological and Production Responses to Feeding Schedule in Lactating Dairy Cows Exposed to Short-Term, Moderate Heat Stress. J Dairy Sci 85, 730-7

Robertshaw D (2006) Mechanisms for the control of respiratory evaporative heat loss in panting animals. J Appl Physiol 101, 664-8

Soch M, Matouskova E, Travnicek J (2000) The Microclimatic conditions in cattle and sheep stables at selected farms in Sumava. Proceedings from the 3rd International Scientific conference »Agroregion $2000 \ll$, Zootechnical section, Ceske Budejovice, 151-2

Soch M (2005) Effect of environment on selected indices of cattle welfare. University of South Bohemia, Ceske Budejovice, Czech Republic

Statistix 8 (2004) Statistix, 8th ed, McGraw-Hill/Irwin, USA

Taralik K (1998) Variability in the milk production of Holstein-Friesian cows according to the agroecological regions of Hungary. ArchTierz 41, 455-62

Tawfik ES, Mohsen MK, Salem AY, El-Awady HG (2000) Study on Friesian herds raised in Egypt and Germany. I.: Estimate of nongenetic effects and genetic parameters. Arch Tierz 43, 111-4

Thompson JA, Brimacombe M, Calvin JA, Tomaszewski MA, Davidson J, Magee DD (1999) Effects of environmental management on seasonal decrease in milk production in dairy cattle. JAVA 214, 85-8

Yousef MK (1987) Principles of bioclimatology and adaptation. In: Johnson Harold D (Ed) Bioclimatology and the Adaptation of Livestock, World Animal Science, B5, Chapter 3, Elsevier Science Publishers B.V., Amsterdam, The Nederlands, 17-31

West JW (2003) Effects of heat-stress on production in dairy cattle. J Dairy Sci 86, 2131-44

West JW, Mullinix BG, Bernard JK (2003) Effects of hot, humid weather on milk temperature, dry matter intake, and milk yield of lactating dairy cows. J Dairy Sci 86, 232-42

Wollny CBA, Namwaza AG, Makamba TSW, Kottner K (1998) The situation of cattle breeding in Malawi. Arch Tierz 41, 33-44 [in German]

Zähner M, Schrader L, Hauser R, Langhans W, Keck M, Wechsler B (2004) The influence of climatic conditions on physiological and behavioural parameters in dairy cows kept in open stables. Anim Sci 78, 139-47 
Ziegler H, Weniger JH (1990) Performance, thermoregulation and energy metabolism of HolsteinFriesian cows under heat stress. 1st communication: Determination factors of heat tolerance. Züchtungsk 62, 254-64 [in German]

Received 21 February 2008, accepted 14 September 2009.

Corresponding author:

JAN BROUCEK

email: broucek@cvzv.sk

Animal Production Research Centre Nitra, Hlohovecka 2, 94151 Luzianky, Slovakia 